\title{
Development of a packed bed reactor for the removal of aromatic hydrocarbons from soil using laccase/mediator feeding system
}

\author{
Ziva Vipotnik, Michele Michelin *, Teresa Tavares \\ Centre of Biological Engineering, University Minho, Campus de Gualtar, 4710-057, Braga, Portugal
}

\section{A R T I C L E I N F O}

\section{Keywords:}

Laccase-mediator system

Contaminated soil

Polyaromatic hydrocarbons

Degradation

Fungi

\begin{abstract}
A B S T R A C T
Polyaromatic hydrocarbons (PAH) are persistent pollutants of great concern due to their potential toxicity, mutagenicity and carcinogenicity. A biotechnological approach to remove PAH from soil was evaluated in this work using a laccase mediator system. Initially, laccase was produced by fungal co-cultivation, using kiwi peels as substrate. The produced laccase was applied to PAH contaminated soil to evaluate its efficiency on enzymatic bioremediation. Results showed that laccase mediator system was effective in the degradation of pyrene, fluorene, chrysene and a lower extension anthracene. Mediators improved the PAH degradation and natural mediators (ferulic acid and p-coumaric acid) were as effective as the synthetic mediator ABTS. However, the process was not effective in the benzo[a]pyrene degradation, one of the most recalcitrant and toxic PAH. This low degradation rate could be related to the low activity of the laccase mediator system in an environment lacking water. To overcome this issue, a PAH contaminated soil degradation system was developed in packed bed reactor (PBR) fed with laccase/mediator. Continuous flow of laccase/mediator improved the PAH degradation, achieving $74.8 \%, 71.9 \%, 72.2 \%, 81.8 \%$ and $100 \%$ degradation for fluorene, anthracene, phenanthrene, chrysene and pyrene, respectively. This system was able to degrade $96 \%$ benzo[a]pyrene, which was $90 \%$ higher than the degradation in batch system. Results indicated that the produced laccase as well as the fed-batch degradation system developed in PBR could be successfully applied in the degradation of soil PAH pollutants, with the advantage of achieving higher degradation rates than in simple batch, as well as being a faster and simpler process than microorganism bioremediation.
\end{abstract}

\section{Introduction}

Polycyclic aromatic hydrocarbons (PAH) are highly toxic organic pollutants, with a structure consisting of two or more fused benzene rings. They are mainly accumulated in sediments and soil due to incomplete combustion or pyrolysis of various organic materials, such as coal, oil, petroleum gas and wood (Li et al., 2019). PAH in the soil can be harmful to people's health through the food chain and therefore, soil pollution by PAH is of great concern (Alexander et al., 2008).

The U.S. Environmental Protection Agency (EPA) has recognized sixteen PAH as priority pollutants due to their high toxicity, mutagenic and carcinogenic potential (Keith, 2015; Xu et al., 2020). As established in many previous studies, the major drawback for the bioremediation of PAH is their low water solubility and subsequent low degradation rates. $\mathrm{PAH}$ degradation rate is reduced with increasing benzene rings. Therefore, with increasing molecular weight also toxicity increases. For example, benzo[a]pyrene, a five rings molecule of high molecular weight, is one of the most recalcitrant and toxic PAH (Li et al., 2010).

The degradation of PAH present in the environment includes volatilization, photo-oxidation, chemical oxidation, adsorption on soil particles and leaching (Haritash and Kaushik, 2009; Wang et al., 2018). However, the cost and adverse environmental effects caused by these methods discourage their widespread practice. Bioremediation is an environmentally friendly, economical and efficient method to degrade and transform PAH to non-toxic compound and has been presented as a soil clean-up technique. However, studies have shown that the success of $\mathrm{PAH}$ bioremediation has been limited by the failure to remove high-molecular-weight PAH (Ogbonna et al., 2012). Additionally, studies with soil are by far more complicated than with liquid culture, mainly because of the heterogeneity of soil besides many other factors that should be considered such as desorption and bioavailability of PAH (Kadri et al., 2017). Despite the great effort in the development of microbiological technologies to rehabilitate PAH contaminated soil, microbes usually require special conditions, where the toxicity of PAH

\footnotetext{
* Corresponding author.

E-mail address: mimichelin@ceb.uminho.pt (M. Michelin).
} 
metabolites is of particular concern (Bamforth and Singleton, 2005). At long term, they may restrain the application of bioremediation, especially where there is heavy contamination. Therefore, enzyme bioremediation can be another option that should be considered.

Laccase (EC 1.10.3.2) is a polyphenol oxidase containing four copper ions, which catalyse the oxidation reaction in the presence of oxygen and leading to the decomposition of phenolic compounds (Kirst Tychanowicz et al., 2006; Viswanath et al., 2014). Laccase has strong stability and very low substrate specificity that makes it suitable for PAH degradation (Fernández-Fernández et al., 2013). Comparing with microorganism degradation, enzyme-catalysed reactions are faster and have higher decomposition efficiencies, lower toxicity, a wide application range and constitute a simple operation. However, the relatively low redox potential of laccase is its main limitation, which has been overcome by using redox mediators like ABTS (2,2'-azinobis-(3-ethylbenzothiazoline-6-sulfonate)) or 1-hydroxybenzotriazole (HBT), that allow the oxidation of non-phenolic compounds with higher redox potentials (Upadhyay et al., 2016). Laccase mediator system (LMS) was first applied to the biodegradation of lignin. Because of its vast reaction capabilities as well as the broad substrate specificity, it also possesses great biotechnological potential (Kunamneni et al., 2008).

Synthetic mediators, as ABTS and HBT, promote the oxidation of PAH by laccase. However, the most relevant disadvantages of all known effective mediator compounds are the high price, some toxic effects and also the eventual inactivation of laccase during oxidation by radicals mediators (Johannes and Majcherczyk, 2000; Viswanath et al., 2014), which led to the search for alternative mediators. On the other hand, natural compounds such as phenolic ones derived from lignin degradation (acetosyringone, syringaldehyde, vanillin, acetovanillone, ferulic acid and $p$-coumaric acid) can be obtained at low cost or for free because they exist abundantly in nature and do not produce any toxicity in the environment (Vasconcelos et al., 2000). They are capable of promoting similar or even better PAH degradation results through LMS (Bhattacharya et al., 2014; Li et al., 2010).

Many research efforts have been made to find a suitable process for the remediation of PAH contaminated soil. However, most works using laccase were focused on a liquid system (without soil) and using a synthetic mediator, such as ABTS or HBT (Ike et al., 2019; Li et al., 2014a, 2014b; Liu and Hua, 2014; Punnapayak et al., 2009). Additionally, it has been reported that the low PAH degradation rates in the soil are due to the low activity of the laccase-mediator system in an environment lacking water (Li et al., 2010). In the studied cases, and to the best of the authors' knowledge, this is the first time that the PAH degradation in soil through a laccase mediator system has been studied in a packed bed reactor (PBR) in fed-batch mode. Thus, the objective of the present work was to develop a PAH degradation system in soil using PBR with a continuous flow of laccase-mediator to overcome the problem of water limitation in the environment. For that, first, the laccase production by solid-state fermentation (SSF) was performed, using kiwi peels (agroindustrial residue) as a support-substrate for fungal co-cultivation, to be applied in the degradation of six PAH (fluorene, anthracene, phenanthrene, pyrene, chrysene, benzo[a]pyrene) in soil. Furthermore, the effect of natural laccase mediators on PAH degradation, such as ferulic acid and $p$-coumaric acid, was evaluated and compared to the effect of the synthetic mediator ABTS. The efficiency in the PAH degradation in soil using a PBR in fed-batch mode was demonstrated compared to PAH degradation in batch mode.

\section{Material and methods}

\subsection{Fungal strains}

Three fungal strains were studied in this work: Trichoderma viride (EXF8977), Penicillium chrysogenum (EXF1818) and Irpex lacteus (MUM 04.98). EXF strains were obtained from Infrastructural Centre Mycosmo, MRIC UL, Slovenia and the MUM strain from Fungal Culture Collection -
Micoteca da Universidade do Minho, Portugal. Stock cultures were maintained on malt extract agar plates, at $4{ }^{\circ} \mathrm{C}$.

\subsection{Substrate pretreatment}

Kiwi peels were cut to $1 \mathrm{~cm}^{2}$ and pretreated with $83 \mathrm{mM}$ of $\mathrm{KOH}$ at room temperature $\left(\approx 26^{\circ} \mathrm{C}\right)$ for $20 \mathrm{~min}$, in a ratio of $1: 3$, to neutralise organic acid (Stredansky and Conti, 1999). After that, they were washed twice with deionised water, dried at $60^{\circ} \mathrm{C}$ and autoclaved at $121^{\circ} \mathrm{C}$ for 15 min prior to use.

\subsection{Enzyme production}

\subsubsection{Fungal inoculum grown in the liquid medium}

The liquid inoculum was prepared by cutting four agar plugs $(5 \mathrm{~mm} \mathrm{x}$ $5 \mathrm{~mm}$ ) from malt extract agar plates. These were extruded through a syringe into $500 \mathrm{~mL}$ Erlenmeyer flasks containing $200 \mathrm{~mL}$ sterile malt extract $(2 \% \mathrm{w} / \mathrm{v})$. Fungi were cultivated at room temperature, with continuous agitation at $120 \mathrm{rpm}$, for 3 days for T. viride and 6 days for $P$. chrysogenum and I. lacteus.

\subsubsection{SSF in Erlenmeyer flasks}

The $500 \mathrm{~mL}$ Erlenmeyer flasks were filled with $200 \mathrm{~g}$ of kiwi peels, autoclaved at $121{ }^{\circ} \mathrm{C}$ for $15 \mathrm{~min}$ and inoculated with $5 \mathrm{~mL}$ of fungal biomass per flask and left at room temperature for 3 weeks. After that, the mixture was suspended in $400 \mathrm{~mL}$ of $50 \mathrm{mM}$ sodium acetate buffer ( $\mathrm{pH} 4.5)$ and mixed continuously (100 rpm) for $1 \mathrm{~h}$ at room temperature. This suspension was filtered through a nylon cloth and centrifuged at $7500 \mathrm{~g}$ for $15 \mathrm{~min}$. The recovered supernatant was used for enzymatic assays. SSF was performed in duplicate.

\subsubsection{SSF in a packed-bed bioreactor}

The horizontal packed-bed bioreactor (PBB) (Fig. 1) consisted of a double jacketed glass column ( $34 \mathrm{~cm}$ length and $3 \mathrm{~cm}$ internal diameter) connected to a filtered-air supply. The air was passed through a $0.45 \mu \mathrm{m}$ cellulose filter and bubbled into distilled water before entering in the column. The airflow was measured and controlled by a flowmeter (Aalborg Instruments \& Controls, Inc., USA). The bioreactor and $50 \mathrm{~g}$ of kiwi peels as substrate were previously sterilized separately. The substrate was inoculated with $2 \mathrm{~mL}$ of fungal inoculum suspension and mixed. After that, the column was filled with the inoculated substrate and maintained at room temperature for 3 weeks. SSFs were performed in duplicate, at different aeration rates of $0.05 \mathrm{~L} \mathrm{~min}^{-1}, 0.1 \mathrm{~L} \mathrm{~min}^{-1}$ and $0.2 \mathrm{~L} \mathrm{~min}^{-1}$. After SSF, the fermented substrate was transferred to 500 $\mathrm{mL}$ Erlenmeyer flasks to proceed with the enzyme extraction, as described previously.

\subsection{Laccase and protein determination}

Laccase activity was measured using a spectrophotometer (BioTek Synergy HT) at $420 \mathrm{~nm}$ by the oxidation of 2,2-azino-bis-[3-ethyltiazoline-6-sulfonate] (ABTS, Sigma Aldrich) in $0.1 \mathrm{M}$ sodium acetate buffer, pH 5.0, at $30{ }^{\circ} \mathrm{C}$ (Bourbonnais and Paice, 1990). One unit of enzyme activity was defined as $1 \mu \mathrm{mol}$ of substrate oxidized per minute. Protein was determined through Bradford's method.

\subsection{Soil preparation}

Naturaduba Agro soil (Gintegral - Gestão Ambiental, S.A.), presenting $49.1 \%$ organic material, $0.99 \% \mathrm{~N}, 0.20 \% \mathrm{P}_{2} \mathrm{O}_{5}, 0.49 \% \mathrm{~K}_{2} \mathrm{O}$, $2.17 \% \mathrm{Ca}, 0.26 \% \mathrm{Mg}, 0.17 \% \mathrm{~S}, 32.2 \%$ humidity and $\mathrm{pH} 7.2$ was used in this work. The soil was first heated for two days at $60{ }^{\circ} \mathrm{C}$. For $\mathrm{pH}$ adjustment to 5.0, $0.43 \mu \mathrm{l}$ of $1 \mathrm{M} \mathrm{HCl}$ was mixed in $10 \mathrm{~mL}$ of distilled water and $5 \mathrm{~g}$ of soil, vortexed for $2 \mathrm{~min}$, left at room temperature for 30 $\mathrm{min}$, and after that, the $\mathrm{pH}$ was confirmed.

Six EPA-priority PAH were used in this study (Table 1 ). They exist as 


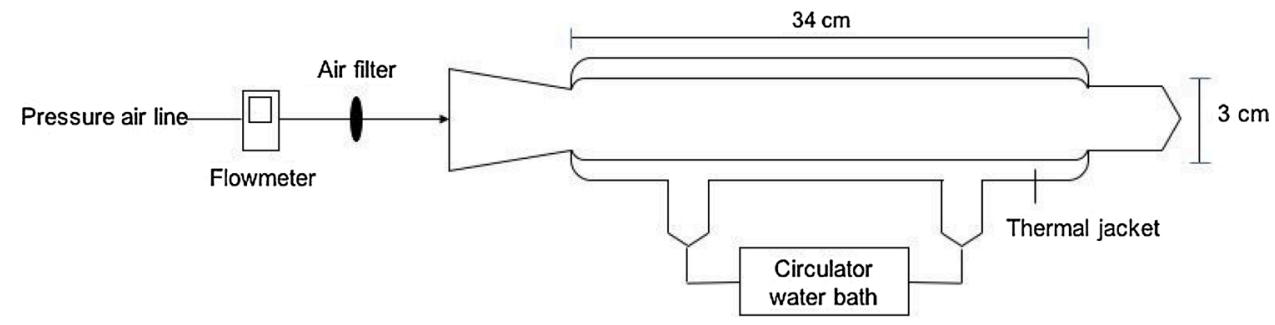

Fig. 1. Horizontal packed-bed bioreactor design for laccase production.

Table 1

Structure, molecular weight and ionization potential (IP) value of different polycyclic aromatic hydrocarbons (PAH).

\begin{tabular}{|c|c|c|c|c|c|}
\hline Compound & Structure & $\begin{array}{l}\text { Molecular } \\
\text { weight (g/ } \\
\text { mol) }\end{array}$ & $\begin{array}{l}\text { IP } \\
\text { value } \\
(\mathrm{eV})^{*}\end{array}$ & Purity & Supplier/CAS \\
\hline Fluorene & & 166.219 & 7.89 & $98 \%$ & $\begin{array}{l}\text { Acros } \\
\text { Organics, } \\
\text { CAS 86-73-7 }\end{array}$ \\
\hline Phenanthrene & & 178.229 & 7.91 & $97 \%$ & $\begin{array}{l}\text { Acros } \\
\text { Organics, } \\
\text { CAS 85-01-8 }\end{array}$ \\
\hline Anthracene & & 178.229 & 7.43 & $99 \%$ & $\begin{array}{l}\text { Acros } \\
\text { Organics, } \\
\text { CAS 120-12-7 }\end{array}$ \\
\hline Pyrene & & 202.251 & 7.43 & $98 \%$ & $\begin{array}{l}\text { Acros } \\
\text { Organics, } \\
\text { CAS 129-00-0 }\end{array}$ \\
\hline Chrysene & & 228.288 & 7.59 & $95 \%$ & $\begin{array}{l}\text { Sigma- } \\
\text { Aldrich, CAS } \\
218-01-9\end{array}$ \\
\hline $\begin{array}{c}\text { Benzo[a] } \\
\text { pyrene }\end{array}$ & & 252.309 & 7.12 & $96 \%$ & $\begin{array}{l}\text { Sigma- } \\
\text { Aldrich, CAS } \\
50-32-8\end{array}$ \\
\hline
\end{tabular}

" (Levin and Lias, 1982).

crystalline solids at room temperature. Thus, an amount of $1000 \mathrm{mg}$ of each $\mathrm{PAH}$ was added to $1000 \mathrm{~mL}$ of acetonitrile and used to contaminate soil, giving a desired final concentration mixture.

\subsection{Degradation assays}

PAH degradation was evaluated using laccase enzyme and LMS in amber laboratory bottle, namely laccase-batch degradation, and in packed bed reactor (PBR), namely laccase-fed degradation.

Laccase batch degradation was set up into $100 \mathrm{~mL}$ amber laboratory bottle with $20 \mathrm{~g}$ of soil at $\mathrm{pH} 5.0$, containing $2 \mathrm{~mL}$ of the PAH mixture appropriately diluted to obtain the concentrations of 100, 300 and 600 ppm of a total mixture of the compound. A laccase load of $2 \mathrm{U} / \mathrm{mL}$ (approx. $4 \mathrm{~mL}$ ) was used for the PAH degradation. The addition of $1 \mathrm{mM}$ (approx. $2 \mathrm{~mL}$ ) of ABTS, coumaric acid and ferulic acid mediators was also evaluated. The degradation was performed in duplicate at $30^{\circ} \mathrm{C}$, in the dark, for 5 days. Samples were taken on days 0,3 and 5 for evaluation of PAH degradation by UHPLC. The boiled enzyme was used as a control.

Laccase-fed degradation was set up in PBR (Fig. 2), consisting of a vertical glass column ( $25 \mathrm{~cm}$ length, $3 \mathrm{~cm} \emptyset$, and $3.5 \mathrm{~cm}$ width) filled with contaminated soil ( $100 \mathrm{~g}$ soil spiked with $50 \mathrm{~mL}$ of the PAH mixture at $300 \mathrm{ppm}$ of each compound). A load of $2 \mathrm{U} / \mathrm{mL}$ of laccase and $1 \mathrm{mM}$ of the mediator were added, in a continuous flow of $0.015 \mathrm{~mL} / \mathrm{min}$, using a laboratory peristaltic pump (Masterflex, Cole-Parmer). The laccase flow was refreshed each second day. In order to avoid heterogeneous degradation, laccase solution was equally distributed over the whole contaminated soil through an inner tube with small holes in the middle of the column. This procedure was done in duplicate and performed for 25 days at room temperature. Soil samples were taken each 5 days for

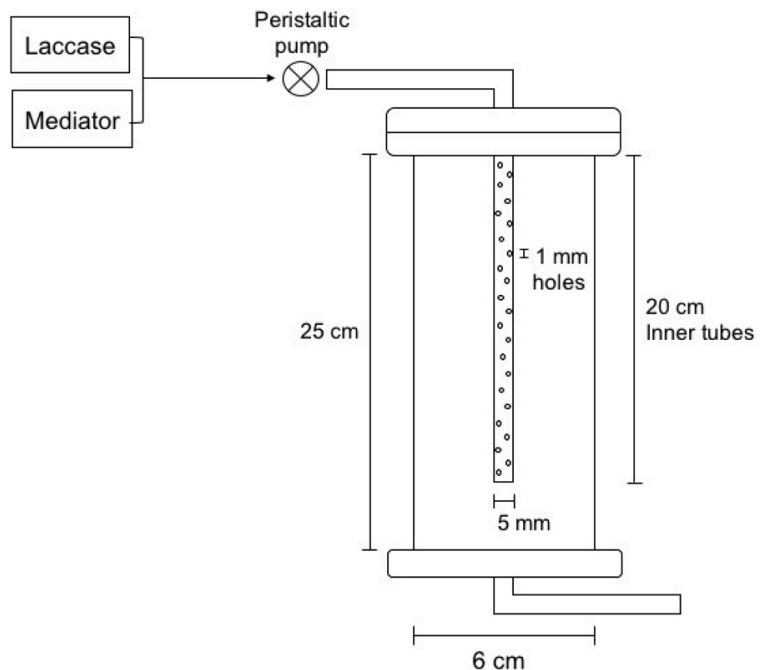

Fig. 2. Packed-bed reactor design for PAH degradation, with an inner tube.

PAH concentration measurement by UHPLC and the assessment of removal efficiency.

\subsection{PAH extraction}

Acetonitrile was used to extract PAH from the soil, for that $1.5 \mathrm{~mL}$ of it was added to $0.5 \mathrm{~g}$ of soil sample and extraction was carried out using rotating shaker at $160 \mathrm{rpm}$ for $30 \mathrm{~min}$ and another $10 \mathrm{~min}$ in an ultrasound bath. The samples were centrifuged at $8000 \mathrm{~g}$, and the supernatant was transferred to $2 \mathrm{~mL}$ Eppendorf tubes for UHPLC analyses.

\subsection{UHPLC analyses}

The quantification of the six selected PAH was performed by ultrahigh-performance liquid chromatography, using a Shimadzu Nexera X2 (Shimadzu, USA) with one multi-channel pump (LC-30AD), an autosampler (SIL30AC), an oven (CTO-20AC), a diode array detector (M-20A) and a system controller (CBM-20A) with built-in software (LabSolutions). For the PAH quantification, a Kinetex PAH C18 column (Phenomenex, Inc. CA, USA) was used. The mobile phase was ultrapure water (pump A) and acetonitrile (pump B). Starting mobile phase composition was $51 \% \mathrm{~A}$, decreased to $4.5 \% \mathrm{~A}$ in $12.03 \mathrm{~min}$, remaining in this percentage until $16.3 \mathrm{~min}$ and increased again to $51 \%$ (17.25 $\mathrm{min}$ ) and remaining in this percentage for $2.35 \mathrm{~min}$. The flow rate was $0.6 \mathrm{~mL} / \mathrm{min}$, and samples were monitored by a diode array detector from 190 to $400 \mathrm{~nm}$, and chromatograms were extracted at $252 \mathrm{~nm}$. Column oven was set at $25^{\circ} \mathrm{C}$, and the injection volume was $15 \mu \mathrm{L}$. 


\section{Results and discussion}

\subsection{Laccase screening}

A screening of laccase producing fungi was performed, aiming to produce high levels of laccase to be applied in PAH degradation. For that, three fungal strains were evaluated through SSF, using kiwi peels as substrate at $\mathrm{pH} 4.5$ and 7.0. SSF mimics the conditions under which fungi grow naturally (Singh Nee Nigam and Pandey, 2009) in lignocellulosic residues. The polysaccharides and lignin present in these materials act as growth and induction substrate, promoting a better fungal growth (Couto and Toca-Herrera, 2007) and the production of extracellular enzymes (Brijwani and Vadlani, 2011), including laccase (Rodríguez Couto and Sanromán, 2005), while making the process more economical (Couto and Toca-Herrera, 2007).

Kiwi peels is an interesting residue from food processing industry due to their high availability and low cost (Rosales et al., 2005). There was 35,410 tons of kiwi fruit produced in Portugal in 2018, representing $1.82 \%$ of world production. However, up to $30 \%$ represent peels. Those contain $10.46 \%$ moisture, $4.02 \%$ ash, $3.84 \%$ protein, $2.10 \%$ lipids, $53.73 \%$ carbohydrates, $6.93 \%$ soluble and $18.92 \%$ insoluble dietary fibres (Soquetta et al., 2016), frees sugar and fatty acid (Dias et al., 2020), and the skin of fruits also contain higher mineral content than their respective edible parts (Soquetta et al., 2016). Lignin content contributes to the insoluble dietary, inducing laccase production by the fungal species.

The higher enzymatic levels were obtained for Trichoderma viride (1.45 U/mL) at $\mathrm{pH} 4.5$ for 3 weeks (Table 2). However, the cocultivation of Trichoderma viridae and Penicillium chrysogenum showed similar production at $\mathrm{pH} 4.5$ at 2 and 3 weeks, besides better growth (see protein data). The co-cultivation of microorganisms is interesting due to the great diversity of laccase that can be produced, with different properties and mode of action, which could be an advantage in the degradation of different PAH. Besides, higher enzyme levels can be achieved with this approach (Hu et al., 2011). Meehnian et al. (2017) also explored the co-cultivation strategy, using the white-rot fungi Daedalea flavida and Phlebia radiata, to enhance the production of the ligninolytic enzymes, including laccase, during pretreatment of cotton stalks in SSF. Laccase production increased to $14.19 \pm 0.85 \mathrm{IU} \mathrm{g}^{-1}$ solid with the co-culture, which was three- and eight-folds higher than to the

Table 2

Laccase production by fungi.

\begin{tabular}{|c|c|c|c|c|c|c|c|}
\hline \multirow{2}{*}{ Strain } & \multirow{2}{*}{$\mathrm{pH}$} & \multicolumn{3}{|c|}{ Laccase activity (U/mL) } & \multicolumn{3}{|c|}{ Protein (mg/mL) } \\
\hline & & 1 week & 2 weeks & 3 weeks & 1 week & 2 weeks & 3 weeks \\
\hline IL & 4.5 & $\begin{array}{l}0.60 \pm \\
0.01\end{array}$ & $\begin{array}{l}0.58 \pm \\
0.02\end{array}$ & $\begin{array}{l}0.93 \pm \\
0.18\end{array}$ & $\begin{array}{l}1.43 \pm \\
0.04\end{array}$ & $\begin{array}{l}1.29 \pm \\
0.02\end{array}$ & $\begin{array}{l}0.87 \pm \\
0.31\end{array}$ \\
\hline IL & 7.0 & $\begin{array}{l}0.53 \pm \\
0.09\end{array}$ & $\begin{array}{l}0.41 \pm \\
0.07\end{array}$ & $\begin{array}{l}0.40 \pm \\
0.09\end{array}$ & $\begin{array}{l}2.08 \pm \\
0.12\end{array}$ & $\begin{array}{l}1.12 \pm \\
0.09\end{array}$ & $\begin{array}{l}2.18 \pm \\
0.35\end{array}$ \\
\hline $\begin{array}{r}\mathrm{IL}+ \\
\mathrm{TV}\end{array}$ & 4.5 & $\begin{array}{l}0.46 \pm \\
0.08\end{array}$ & $\begin{array}{l}0.42 \pm \\
0.09\end{array}$ & $\begin{array}{l}0.94 \pm \\
0.03\end{array}$ & $\begin{array}{l}1.58 \pm \\
0.11\end{array}$ & $\begin{array}{l}0.88 \pm \\
0.03\end{array}$ & $\begin{array}{l}1.59 \pm \\
0.17\end{array}$ \\
\hline $\begin{array}{l}\mathrm{IL}+ \\
\mathrm{TV}\end{array}$ & 7.0 & $\begin{array}{l}0.42 \pm \\
0.22\end{array}$ & $\begin{array}{l}0.58 \pm \\
0.06\end{array}$ & $\begin{array}{l}1.10 \pm \\
0.15\end{array}$ & $\begin{array}{l}2.90 \pm \\
0.03\end{array}$ & $\begin{array}{l}0.70 \pm \\
0.18\end{array}$ & $\begin{array}{l}0.79 \pm \\
0.29\end{array}$ \\
\hline PC & 4.5 & $\begin{array}{l}0.45 \pm \\
0.02\end{array}$ & $\begin{array}{l}0.47 \pm \\
0.01\end{array}$ & $\begin{array}{l}0.70 \pm \\
0.06\end{array}$ & $\begin{array}{l}0.70 \pm \\
0.01\end{array}$ & $\begin{array}{l}2.17 \pm \\
0.12\end{array}$ & $\begin{array}{l}1.84 \pm \\
0.29\end{array}$ \\
\hline PC & 7.0 & $\begin{array}{l}0.98 \pm \\
0.09\end{array}$ & $\begin{array}{l}1.16 \pm \\
0.04\end{array}$ & $\begin{array}{l}1.17 \pm \\
0.09\end{array}$ & $\begin{array}{l}3.48 \pm \\
0.04\end{array}$ & $\begin{array}{l}2.34 \pm \\
0.01\end{array}$ & $\begin{array}{l}1.19 \pm \\
0.20\end{array}$ \\
\hline $\begin{array}{r}\mathrm{PC}+ \\
\mathrm{TV}\end{array}$ & 4.5 & $\begin{array}{l}1.04 \pm \\
0.07\end{array}$ & $\begin{array}{l}1.48 \pm \\
0.07\end{array}$ & $\begin{array}{l}1.39 \pm \\
0.03\end{array}$ & $\begin{array}{l}3.72 \pm \\
0.17\end{array}$ & $\begin{array}{l}1.78 \pm \\
0.04\end{array}$ & $\begin{array}{l}2.80 \pm \\
0.36\end{array}$ \\
\hline $\begin{array}{r}\mathrm{PC}+ \\
\mathrm{TV}\end{array}$ & 7.0 & $\begin{array}{l}0.53 \pm \\
0.08\end{array}$ & $\begin{array}{l}0.54 \pm \\
0.03\end{array}$ & $\begin{array}{l}1.06 \pm \\
0.11\end{array}$ & $\begin{array}{l}0.87 \pm \\
0.20\end{array}$ & $\begin{array}{l}1.91 \pm \\
0.03\end{array}$ & $\begin{array}{l}2.40 \pm \\
0.42\end{array}$ \\
\hline TV & 4.5 & $\begin{array}{l}0.89 \pm \\
0.04\end{array}$ & $\begin{array}{l}0.70 \pm \\
0.05\end{array}$ & $\begin{array}{l}1.45 \pm \\
0.01\end{array}$ & $\begin{array}{l}0.76 \pm \\
0.29\end{array}$ & $\begin{array}{l}1.19 \pm \\
0.09\end{array}$ & $\begin{array}{l}1.63 \pm \\
0.51\end{array}$ \\
\hline TV & 7.0 & $\begin{array}{l}0.54 \pm \\
0.01\end{array}$ & $\begin{array}{l}0.27 \pm \\
0.04\end{array}$ & $\begin{array}{l}0.52 \pm \\
0.05\end{array}$ & $\begin{array}{l}2.37 \pm \\
0.36\end{array}$ & $\begin{array}{l}3.49 \pm \\
0.11\end{array}$ & $\begin{array}{l}4.08 \pm \\
0.22\end{array}$ \\
\hline
\end{tabular}

IL: Irpex lacteus; TV: Trichoderma viride; PC: Penicillium chrysogenum; IL + TV: cocultivation of $I$. lacteus and T. viride; PC + TV: co-cultivation of $P$. chrysogenum and $T$. viride. The fungi were not able to grow in the IL $+\mathrm{PC}$ co-cultivation. pretreatment by monoculture of $D$. flavida and $P$. radiata, respectively.

Although the $\mathrm{pH}$ is not controlled during most cultivations, the initial pH is usually set between 4 and 6 prior inoculum (Brijwani et al., 2010). For example, Thurston (Thurston, 1984) reported higher laccase production when fungi were grown in a medium with $\mathrm{pH}$ 5.0. Optimal laccase production from Trametes pubescens was obtained between $\mathrm{pH}$ 3.0 and 4.5 (Strong, 2011). Thus, the co-cultivation of these two species (Trichoderma viridae and Penicillium chrysogenum) at $\mathrm{pH} 4.5$ was used in this work.

\subsection{Laccase production}

Laccase production was performed by SSF using Erlenmeyer flasks and PBR in different aeration rates (Table 3). There are several bioreactor designs used for SSF, but their major limits are heat and mass transfer in solid media (Brijwani et al., 2010). In this work, a horizontal PBR with a double jacketed glass column was used, where laccase production was performed with constant air supply.

The highest values of laccase production $(6.32 \mathrm{U} / \mathrm{mL})$ were obtained in PBR at aeration rates $0.2 \mathrm{~mL} / \mathrm{min}$, following by 0.1 and $0.05 \mathrm{~mL} / \mathrm{min}$ with laccase production of 5.45 and $3.79 \mathrm{U} / \mathrm{mL}$, respectively (Table 3). SSF in Erlenmeyer flasks were performed in different temperatures (room temperature, $30{ }^{\circ} \mathrm{C}$ and $40{ }^{\circ} \mathrm{C}$ ), presenting no significant differences among the results of laccase production $(2 \mathrm{U} / \mathrm{mL})$. These assays aimed to assess the overall effect of temperature, as well as the overall effect of aeration on laccase production by SSF.

Oxygen supply showed to be one limiting factor for microorganism growth (data not shown), as well as for laccase production, which is frequently reported for aerobic bioprocesses. Another limiting factor in laccase production is temperature, being that the optimal temperature of laccase production diverse from one to another fungal strain. In the presence of light, temperatures of $25{ }^{\circ} \mathrm{C}$ is generally accepted as optimum, but in case of dark conditions, the optimum temperature generally is $30{ }^{\circ} \mathrm{C}$ (Bamforth and Singleton, 2005; Thurston, 1984), reducing the production when fungi are cultivated at temperatures higher than $30^{\circ} \mathrm{C}$ (Lang et al., 2000).

Rodríguez Couto et al. (2003) tested several bioreactor configurations, such as immersion, expanded-bed and tray, with nylon sponge and barley bran as support. The first two were supplied with humidified air in a continuous flow at $0.5 \mathrm{vvm}$, and the tray reactor was kept at $90 \%$ environmental humidity and passive aeration. Maximum laccase production by $T$. versicolor was reached between $18^{\text {th }}$ and $20^{\text {th }}$ days of cultivation, with $0.23,0.13$ and $0.34 \mathrm{U} / \mathrm{mL}$, respectively. In another work, Rodríguez-Couto (2011) achieved $6 \mathrm{U} / \mathrm{mL}$ laccase by $T$. pubescens under SSF in temporary immersion bioreactor, using sunflower-seed shells as substrate and $60 \mathrm{~L} / \mathrm{h}$ flowrate. Rosales et al. (2007) tested laccase production in a fixed-bed reactor (FBR) and tray reactor on $\mathrm{KOH}$ pretreated orange peels by $T$. hirsute. In FBR laccase production reached $3 \mathrm{U} / \mathrm{mL}$ on $11^{\text {th }}$ day, and in tray reactor, on day $23^{\text {rd }}$ reached $12.7 \mathrm{U} / \mathrm{mL}$. Rosales et al. (2005) also reported laccase production on pretreated kiwi peels and supplementation by ammonium by Trametes hirsute, attaining a value of $5.4 \mathrm{U} / \mathrm{mL}$ on the $13^{\text {th }}$ day. Böhmer et al. (2011) have reported laccase production by $T$. hirsuta in a modular bioreactor, under SSF on a

Table 3

Laccase production by co-cultivation of Trichoderma viride and Penicillium chrysogenum on kiwi-peels.

\begin{tabular}{|c|c|c|c|}
\hline \multicolumn{2}{|c|}{ SSF in lab flasks } & \multicolumn{2}{|c|}{ SSF in packed bed bioreactor* } \\
\hline $\begin{array}{l}\text { Temperature } \\
\left({ }^{\circ} \mathrm{C}\right)\end{array}$ & $\begin{array}{l}\text { Laccase activity (U/ } \\
\mathrm{mL})\end{array}$ & $\begin{array}{l}\text { Airflow (L } \\
\min ^{-1} \text { ) }\end{array}$ & $\begin{array}{l}\text { Laccase activity (U/ } \\
\text { mL) }\end{array}$ \\
\hline RT & $2.21 \pm 0,3$ & 0.05 & $3.79 \pm 0.75$ \\
\hline 30 & $2.22 \pm 0.3$ & 0.1 & $5.45 \pm 0.06$ \\
\hline 40 & $2.21 \pm 0.8$ & 0.2 & $6.32 \pm 0.71$ \\
\hline
\end{tabular}

* SSF in packed bed bioreactor were performed at room temperature $(\approx 26$ $\left.{ }^{\circ} \mathrm{C}\right)$. 
mixture of pine wood chips and orange peel, achieving around $0.7 \mathrm{U} / \mathrm{mL}$ and $1.1 \mathrm{U} / \mathrm{mL}$ in media supplemented with copper sulfate and xylidine. Another work has also reported the laccase production by white-rot fungi in a bioreactor under submerged fermentation (Hailei et al., 2015).

Optimal temperature and $\mathrm{pH}$ of laccase activity are presented in Fig. 3. Maximal activity was reached at $\mathrm{pH} 5.0$ and $30^{\circ} \mathrm{C}$. Similar optimal conditions were reported by Patel and Gupte (Patel and Gupte, 2016) and Chenthamarakshan et al. (2017) for laccase from Tricholoma giganteum and Marasmiellus palmivorus, respectively, produced under SSF. Regarding the temperature stability, the enzyme showed higher activity in more acid $\mathrm{pH}$, i.e. $3.5-5.0$, being significantly reduced at $\mathrm{pH}$ 5.5 and 6.0. Regarding the temperature, activity decreased gradually from temperatures higher than $30{ }^{\circ} \mathrm{C}$. The effect of temperature on laccase stability is showed in Table 4 . The stability was higher at temperatures from $25{ }^{\circ} \mathrm{C}$ to $30{ }^{\circ} \mathrm{C}$, remaining more than $70 \%$ of the initial activity, after 5 days of incubation. At $35^{\circ} \mathrm{C}$, around $64.4 \%$ and $42.6 \%$ of the laccase activity were verified after 3 and 5 days of incubation, respectively. The enzyme showed low stability at $40^{\circ} \mathrm{C}$, presenting 35.2 $\%$ and $10.5 \%$ of residual activity after 3 and 5 days of incubation, respectively. Laccase from $T$. modesta was stable at $40{ }^{\circ} \mathrm{C}$ for $180 \mathrm{~min}$, with maximum stability at $50{ }^{\circ} \mathrm{C}$ (stable for $6 \mathrm{~h}$ ), but at higher temperatures $\left(60^{\circ} \mathrm{C}\right)$ activity decreased (Nyanhongo et al., 2002). Laccase from wild and mutant Shiraia sp. was utterly stable at $35^{\circ} \mathrm{C}$ for $30 \mathrm{~h}$, but at $50{ }^{\circ} \mathrm{C}$ the stability gradually decreased (Du et al., 2015). It is important to highlight that in the current work, the stability was evaluated for longer incubation time since the PAH degradation studies required prolonged time incubation.

Regarding the $\mathrm{pH}$ stability, the laccase showed high stability at $\mathrm{pH}$ 5.0 , remaining almost $80 \%$ of the activity after 5 days of incubation (Table 5). At $\mathrm{pH} 4.0$ and 6.0 the enzyme still presented $\approx 70 \%$ of activity, while in $\mathrm{pH} 7.0$, around $52 \%$ was verified after 5 days of incubation. However, at $\mathrm{pH} 3.0$ the relative laccase activity was significantly reduced to $27.1 \%$ on day 5. Góralczyk-Binkowska et al. (2020) reported more than $80 \%$ stability for laccase from Nectriella pironii at $\mathrm{pH}$ from 4.0 to 9.0; however, the stability was evaluated for only $3 \mathrm{~h}$. The $\mathrm{pH}$ could affect the enzymatic activity by changing the electrostatic properties of the protein surface and reaction centre, or by influencing the stability of the enzyme (Bonomo et al., 2001). Considering the removal of PAH in contaminated soil, the high stability of the enzyme at room temperature, as well as in $\mathrm{pH}$ from 4.0 to 7.0 is very important for its application in this proposal.
Table 4

Effect of temperature on laccase stability at $\mathrm{pH}$ 5.0.

\begin{tabular}{llll}
\hline \multirow{2}{*}{ Temperature $\left({ }^{\circ} \mathrm{C}\right)$} & \multicolumn{3}{l}{ Relative laccase activity (\%) } \\
\cline { 2 - 4 } & 0 days & 3 days & 5 days \\
\hline 25 & 100 & $93.25 \pm 3.4$ & $72.60 \pm 4.6$ \\
30 & 100 & $89.85 \pm 4.6$ & $77.54 \pm 3.8$ \\
35 & 100 & $64.44 \pm 4.8$ & $42.59 \pm 3.7$ \\
40 & 100 & $35.15 \pm 2.7$ & $10.50 \pm 2.4$ \\
\hline
\end{tabular}

Table 5

Effect of $\mathrm{pH}$ on the laccase stability at $30^{\circ} \mathrm{C}$.

\begin{tabular}{llll}
\hline \multirow{2}{*}{$\mathrm{pH}$} & \multicolumn{3}{l}{ Relative laccase activity (\%) } \\
\cline { 2 - 4 } & 0 day & 3 days & 5 days \\
\hline 3.0 & 100 & $91.1 \pm 0.4$ & $27.1 \pm 0.6$ \\
4.0 & 100 & $87.5 \pm 1.2$ & $66.3 \pm 2.2$ \\
5.0 & 100 & $89.65 \pm 0.4$ & $78.5 \pm 1.3$ \\
6.0 & 100 & $72.7 \pm 5.6$ & $68.8 \pm 6.7$ \\
7.0 & 100 & $71.1 \pm 3.3$ & $52.4 \pm 4.5$ \\
\hline
\end{tabular}

\subsection{PAH degradation in soil}

The role of different mediators in the degradation of PAH in soil by laccase was evaluated in batch (Erlenmeyer flasks) and feed-batch in PBR. Laccase was capable of degrading the selected PAH, and the degradation rates increased with the addition of a mediator. Results showed that the laccase obtained from co-cultivation of Penicillium chrysogenum and Trichoderma viride on kiwi peels with an appropriate mediator promotes the degradation of fluorene, anthracene, pyrene, chrysene and benzo[a]pyrene, in concentrations ranging from $100 \mathrm{ppm}$ till $600 \mathrm{ppm}$, in soil.

Some of the relevant parameters determining laccase activity in PAH degradation is the mediator and $\mathrm{pH}$, as well as the incubation temperature for maximal laccase activity (Jin et al., 2016). In general, the mediators improve the degradation rates of PAH. Regarding the temperature, a higher temperature is preferable for laccase catalysis, but it also leads to a faster loss of activity (Aktaş and Tanyolaç, 2003; Zhang et al., 2008). Thus, the use of room temperature can be interesting, mainly concerning naturally contaminated environments. In this work, a higher degradation rate of $\mathrm{PAH}$ in soil was achieved at $30{ }^{\circ} \mathrm{C}$ when compared to $40{ }^{\circ} \mathrm{C}$ (data not shown). PAH degradation was assessed for 3 and 5 days in Erlenmeyer flasks, being the maximum degradation rates reached with 5 days for all compounds (Fig. 4).

Concerning PAH degradation in soil, it has been reported that the

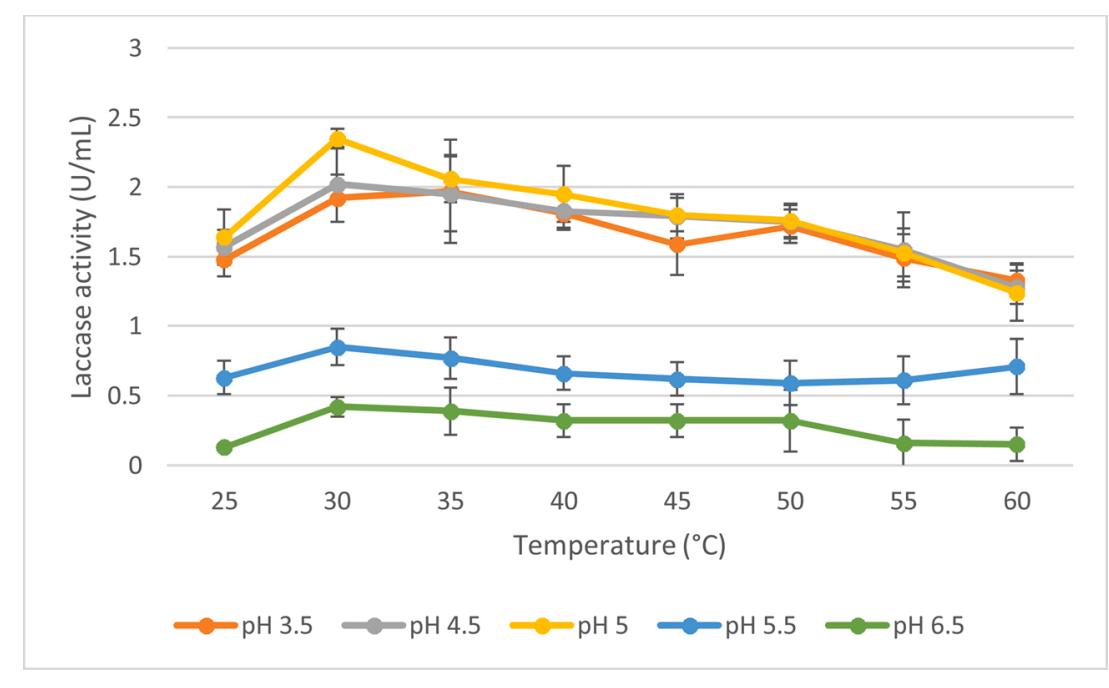

Fig. 3. Laccase activity at different temperatures and $\mathrm{pH}$. 

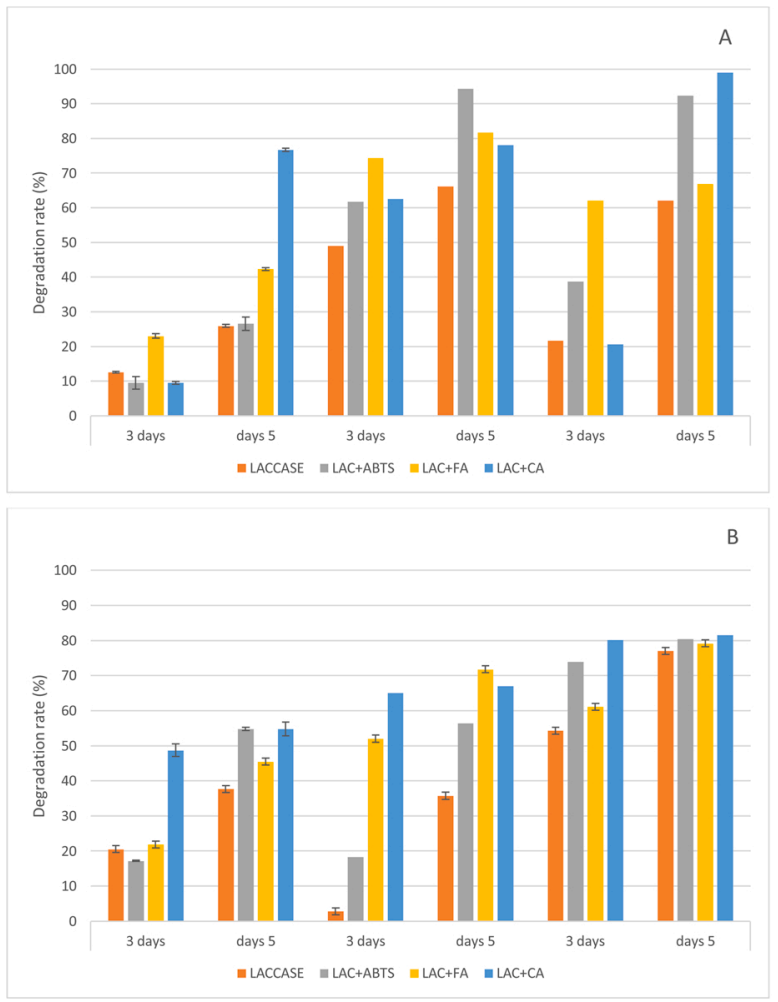

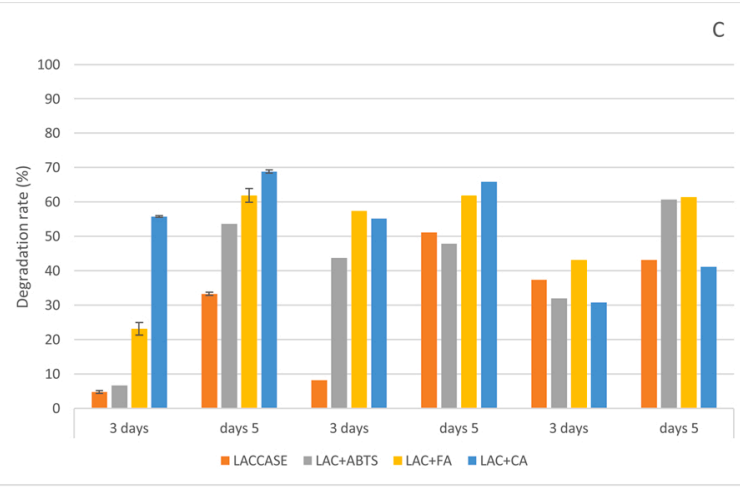

D

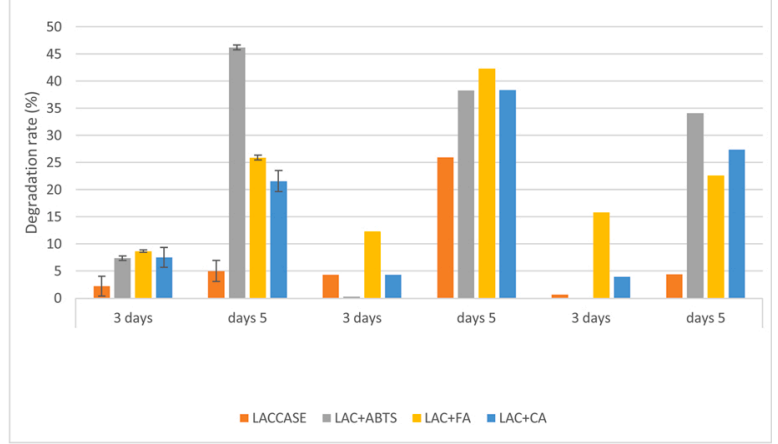

E

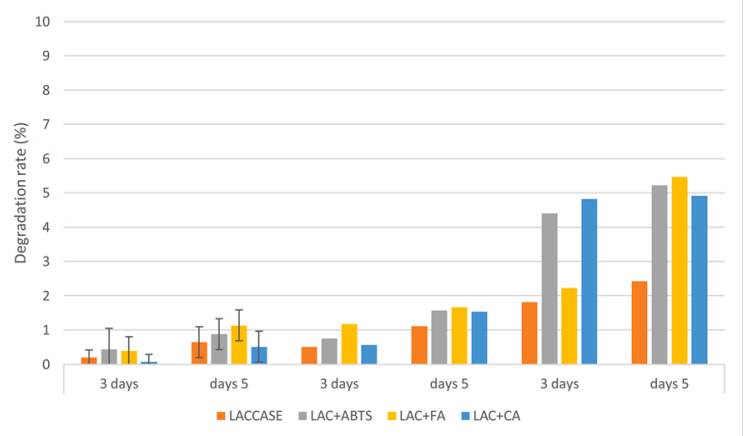

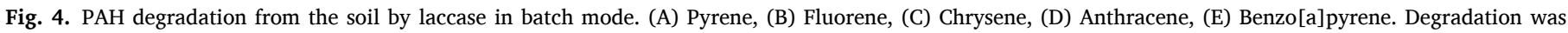
performed at $30^{\circ} \mathrm{C}$, in the dark, using different concentration of PAH in Erlenmeyer flasks. The graphs are presented in a different scale.

distribution of PAH in soil depends mainly on the PAH hydrophobicity and their affinity towards microcompartments of the aggregates (Styrishave et al., 2012). PAH molecules with higher hydrophobicity and more aromatic rings (see Table 1) present stronger sorption affinity (Zhang et al., 2014). Thus, these molecules diffuse into hydrophobic parts (ageing) over time, decreasing their bioavailability to be degraded by microorganisms and/or their enzymes, and consequently hindering their removal (Allard et al., 2000). In the current work artificially contaminated soil was used. So, the desorption rate of PAH in soil is expected to be higher than naturally contaminated soil, as observed by Huesemann et al. (2004) for anthracene degradation in freshly spiked soil (72 \% degradation) and aged soil (34\% degradation).

In the current work, pyrene was the most degraded compound, achieving $99 \%$ degradation with laccase mediated by $p$-coumaric acid, in the assay containing $600 \mathrm{ppm}$ of the compound (maximal degradation rate). Regarding the other mediators, $92 \%$ of the compound was degraded with ABTS, $67 \%$ with ferulic acid, and $62 \%$ with only laccase (without mediator). Thus, LMS allowed an increment of more than $35 \%$ in the degradation rate of $600 \mathrm{ppm}$ of the compound. However, for ABTS and ferulic acid as mediators, the maximal degradation rates were achieved in the assays containing $300 \mathrm{ppm}$ of the compound, being the degradation rate of $94 \%$ and $82 \%$, respectively. Laccase (without mediator) was able to degrade $66 \%$ of pyrene at $300 \mathrm{ppm}$ in soil (Fig. 4A).

All mediators were effective for fluorene degradation, being the degradation rate lightly higher with $p$-coumaric as mediator. Additionally, maximal degradation was observed in the assay with $600 \mathrm{ppm}$ fluorene, where the degradation rates achieved $82 \%$ with p-coumaric, $80 \%$ with ABTS and $79 \%$ with ferulic acid. Laccase (without mediator) was able to degrade $77 \%$ of the pollutant (Fig. 4B). Regarding, chrysene, the maximal degradation rate was also achieved with laccase mediated by $p$-coumaric, at $100 \mathrm{ppm}$ of the compound, achieving $69 \%$ degradation. At higher concentrations, the degradation rate decreased, with maximal removal of $41 \%$ at $600 \mathrm{ppm}$. Laccase mediated with ferulic acid was able to degrade $62 \%$ of chrysene in all concentration assayed. Maximal degradation with laccase plus ABTS $(\approx 61 \%)$ was observed at $600 \mathrm{ppm}$ of the compound, while laccase without mediator degraded 51 $\%$ of the compound at $300 \mathrm{ppm}$ (Fig. 4C).

For anthracene degradation, ABTS was the best mediator with $46 \%$ degradation at $100 \mathrm{ppm}$, while for ferulic acid and p-coumaric, 
degradation rates of $42 \%$ and $38 \%$, respectively, were achieved at 300 ppm of the compound. Only $26 \%$ of anthracene was degraded by laccase in the absence of mediator at $300 \mathrm{ppm}$. At $600 \mathrm{ppm}$, the degradation rate decreased significantly for laccase, as well as for most of LMS (Fig. 4D). The lowest degradation was observed with Benzo[a]pyrene. Only $5.4 \%$ degradation was achieved with LMS, while laccase without mediator was able to degrade $2.4 \%$ of the compound (Fig. 4E). Li et al. (2010) studied PAH degradation using laccase from $T$. versicolor in batch and verified a higher degradation rate for anthracene (74.6\%) and benzo[a] pyrene $(56.7 \%)$ mediated with ABTS, except for pyrene in which only $7.5 \%$ degradation was achieved. It is important highlight that in this work, they used a high enzyme load (100 U laccase) and maintained a high humidity in the medium (70\%).

Regarding PBR trials, a laccase/mediator feeding was performed every $48 \mathrm{~h}$ for 25 days aiming to keep laccase activity levels throughout the process and in an attempt to improve the degradation rates. In general, the degradation rate of PAH achieved in PBR was higher than in Erlenmeyer flasks (mainly for benzo[a]pyrene), except for fluorene, where a degradation rate slightly lower $(\approx 7 \%)$ was observed in PBR (Fig. 5). This result could be related to the heterogeneity of soil, as commented previously. However, it should be noticed that the higher moisture content of the soil in the end of the PBR trials ( $86 \%$ in relation to $27 \%$ at the beginning of assay) due to the constant and slow laccase feeding may have helped to improve the degradation rates. PBR has been successful used for degradation of other compounds, such as dyes (Mosleh et al., 2018, 2017, 2016). For example, Mosleh et al. (2018) used a rotating PBR for degradation of pollutant dyes using photocatalyst compounds, as Cu-based nanoparticles, achieving $90 \%$ or more of degradation. They reported some benefits of using rotating PBR compared to conventional reactors, such as high interfacial surface area caused by the rotational speed, which enhances mass transfer and mixing processes. In the current work, a PBR with a microperforated inner tube was used to allow a homogeneous and efficient degradation process.

The most degraded compound was pyrene, $100 \%$ degradation with $p$-coumaric acid as a mediator, being the degradation rates achieved with laccase mediated by ferulic acid and ABTS of $87 \%$ and $83.5 \%$, respectively (Fig. 5A). Surprisingly, benzo[a]pyrene, the most carcinogenic, mutagenic and persistent $\mathrm{PAH}$, was almost totally degraded by laccase mediated by ABTS (96\%) in the PBR system, although laccase with ferulic acid was not far behind, with $5.7 \%$ lower degradation rate (Fig. 5E). This represents an increase of more than $90 \%$ compared to the batch degradation. A crucial factor affecting PAH degradation is their molecular weight that also means their bioavailability (Ghosal et al., 2016). PAH with high molecular weight, such as benzo[a]pyrene (see Table 1) were less degradable in batch degradation, probably due to the higher heterogeneity of the soil which is related to the lack of moisture. Li et al. (2010) reported that LMS works actively in the water environment or in soil with a high capacity of water as in slurry. In this work, they achieved $56.7 \%$ of benzo[a]pyrene degradation in soil with laccase plus ABTS, as commented previously. They suggested that the relatively low degradation rate is probably related to the environment lacking
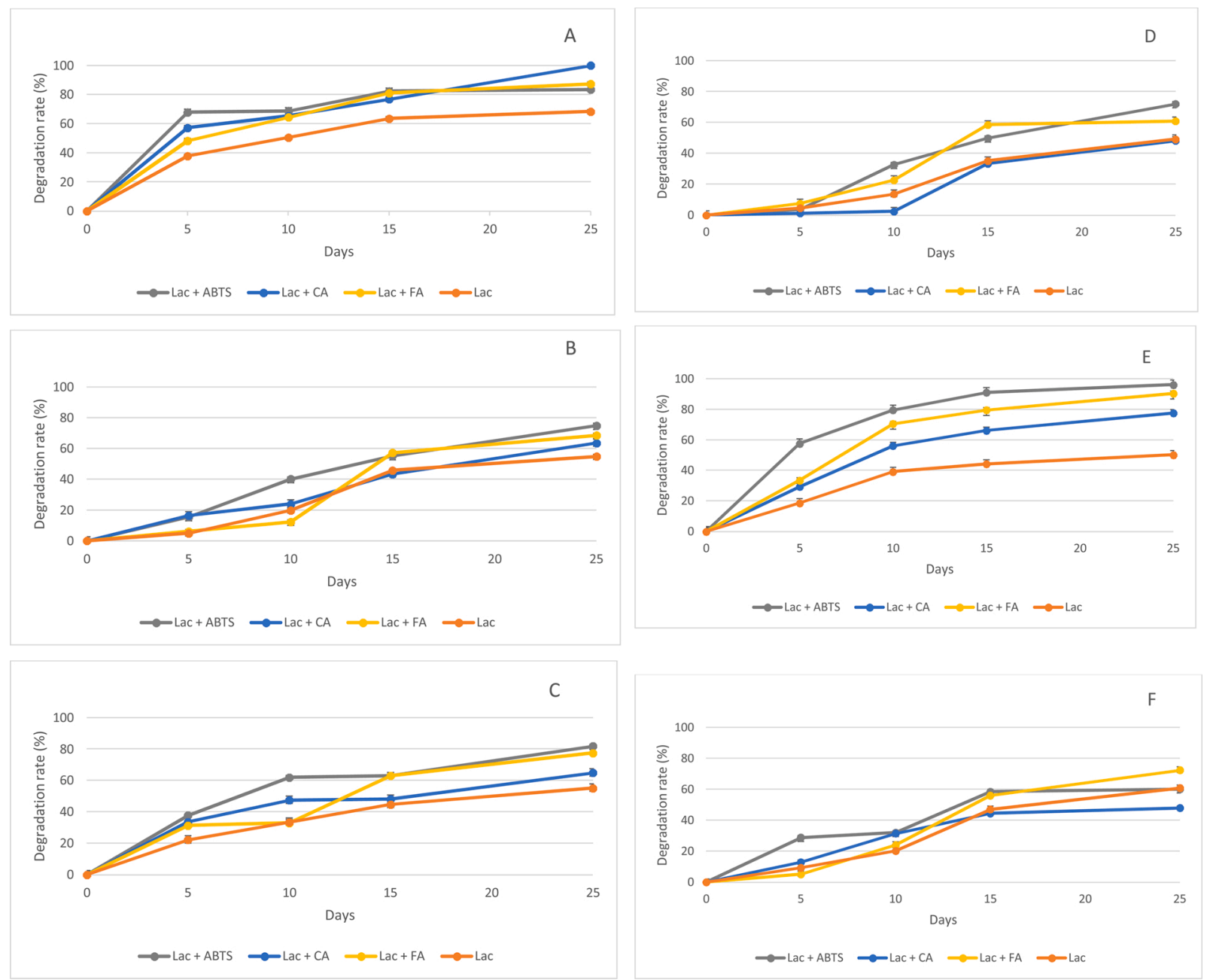

Fig. 5. PAH degradation from the soil in a packed-bed reactor by LMS. (A) Pyrene, (B) Fluorene (C) Chrysene, (D) Anthracene, (E) Benzo[a]pyrene, (F) Phenanthrene. Degradation was performed at room temperature, in the dark, for 25 days, using $300 \mathrm{ppm}$ of PAH. 
water. Wu et al. (2008) achieved $60 \%$ of benzo[a]pyrene degradation in soil with laccase.

The degradation rate achieved for chrysene was 81.8 with ABTS and $77.5 \%$ with ferulic acid (Fig. 5C). Similar degradation rates were achieved for fluorene, phenanthrene and anthracene. Decomposition of fluorene was constant over the entire period of the assay with laccase plus ABTS, achieving $75 \%$ degradation. Degradation rates of 68.5 and $63.5 \%$ were reached with laccase mediated by ferulic acid and $p$-coumaric acid, respectively, at the end of the process (Fig. 5B). Anthracene has started degrading after 5 days with ABTS or ferulic acid as mediators

Table 6

PAH degradation by laccases from different sources.

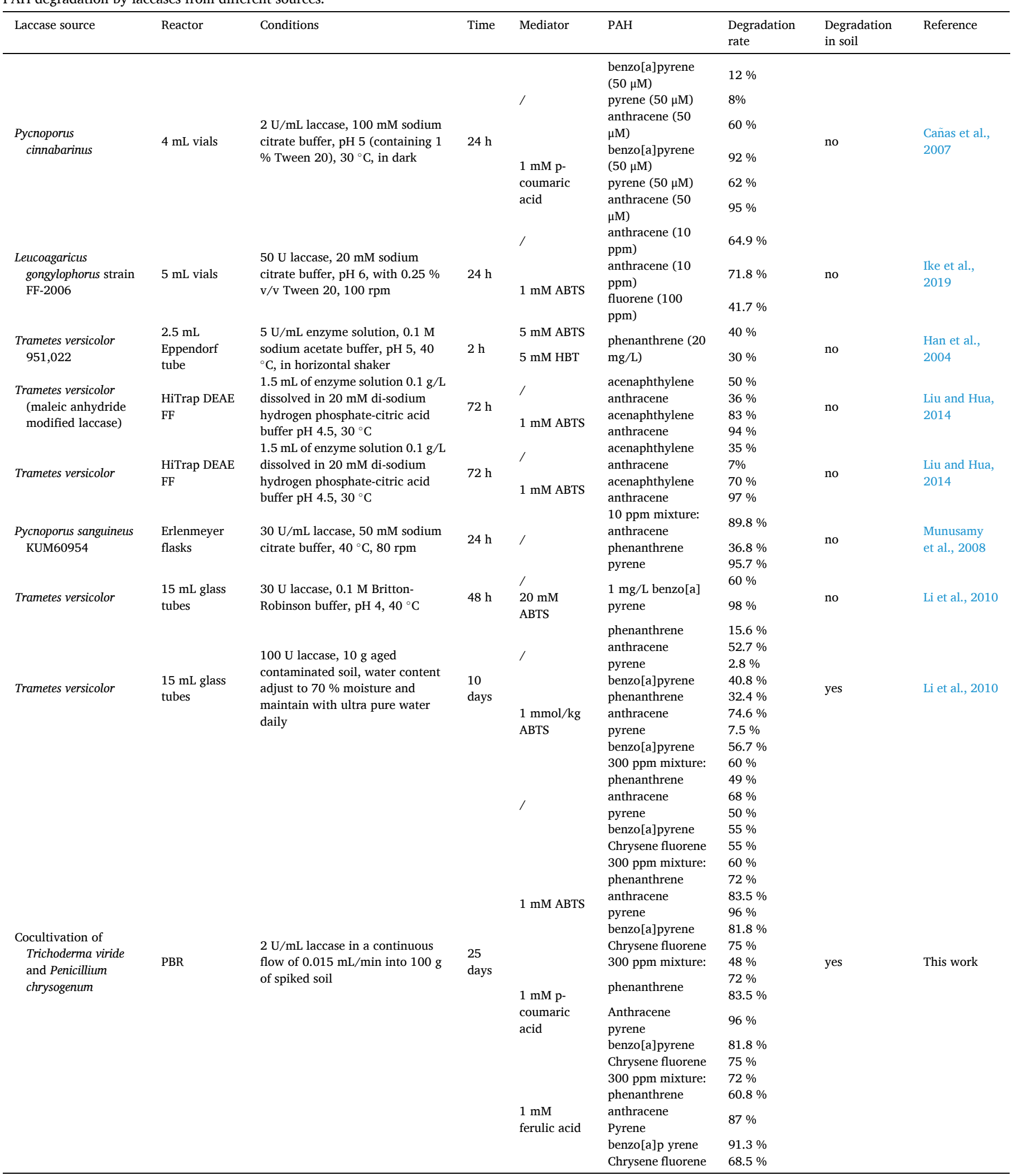


but only started degrading after 10 days with p-coumaric acid, being together with phenanthrene the less degradable pollutant in 25 days of the experiment. They achieved $72 \%$ degradation mediated by ABTS (Fig. 5D). Phenanthrene also achieved $72 \%$ removal, but mediated by ferulic acid, followed by ABTS and by $p$-coumaric acid with 60 and $48 \%$ degradation, respectively (Fig. 5F).

Therefore, all mediators were effective for PAH degradation, achieving at least $72 \%$ degradation. ABTS was found to be the best mediator for benzo[a]pyrene, chrysene, fluorene and anthracene with degradation rates of $96 \%, 82 \%, 75 \%$ and $72 \%$, respectively. Phenanthrene was degraded $72 \%$ with laccase mediated by ferulic acid, and in case of pyrene $100 \%$ degradation was reached with $p$-coumaric acid as mediator. Few works have explored the use of natural mediators for PAH degradation (Cañas et al., 2007; Johannes and Majcherczyk, 2000); however, these works were performed in liquid medium instead of soil. Table 6 presents similar attempts in the area of PAH degradation by laccases and LMS compared to the results obtained in this study. It is also important to note that these degradation rates were achieved with 25 days (maximal degradation time studied). So, a higher degradation rate could be achieved with extended time or possibly with higher laccase loading and mediator.

It has been reported that the specific laccase catalysis is related to the ionization potentials (IPs) of the substrates; therefore, laccase can only oxidize compounds with less than $7.45 \mathrm{eV}$ IP values (Pozdnyakova et al., 2006). Thus, the most degraded compounds should be Benzo[a]pyrene $>$ Pyrene $\geq$ Anthracene $>$ Chrysene $>$ Fluorene $>$ Phenanthrene (see Table 1). In our work, the highest degradation rates were achieved for Pyrene $>$ Benzo[a]pyrene $>$ Chrysene $>$ Fluorene $>$ Phenanthrene $>$ Anthracene in PBR. Not only IP values but also the solubility among PAH is having an impact on their degradation (Pozdnyakova et al., 2006). The solubility of PAH increase for higher temperatures, which in turn influences the bioavailability of PAH molecules (Ghosal et al., 2016). Longer PAH stays in contact with soil, the more irreversible the sorption is, and lesser is the chemical and biological extractability of the contaminants (Ghosal et al., 2016; Luo et al., 2012; Martin, 2000). Li et al. (2010) also reported this only partially justified theory of IPs. IP of each top degradable PAH (anthracene, benzo[a]pyrene and benzo[a] anthracene) was below $7.45 \mathrm{eV}$, but the remaining was in a different order. More, the pyrene with $7.43 \mathrm{eV}$ was poorly degraded. Therefore, they suggest further studies for a full elucidation of the catalytic mechanism of laccase. Han et al. (2004) reported that phenanthrene was degraded only in the presence of $5 \mathrm{mM}$ of ABTS or HBT as mediator with $5 \mathrm{U} / \mathrm{mL}$ of laccase purified from $T$. versicolor 951022, that was able to oxidize $40 \%$ and $30 \%$ of $20 \mathrm{mg} / \mathrm{L}$ of phenanthrene in $2 \mathrm{~h}$, respectively.

Li et al. (2010) observed the highest degradation rate of $1 \mathrm{mg} / \mathrm{L}$ benzo[a]pyrene with laccase plus ABTS after $48 \mathrm{~h}$ incubation, despite there was no significant difference between 24 and $48 \mathrm{~h}$. The experiment was carried out at $40{ }^{\circ} \mathrm{C}, \mathrm{pH} 4.0$, and $30 \mathrm{U}$ of laccase. At the same time, it was tested degradation in soil with $70 \%$ moisture. In 10 days, they observed $40.8 \%$ of degradation with $10 \mathrm{U} / \mathrm{g}$ laccase, and $56.7 \%$ degradation by adding $1 \mathrm{mmol} / \mathrm{kg}$ ABTS. Wu et al. (2008) studied the degradation of PAH in contaminated soil, with different concentration of laccase, i.e. 1, 3 and $10 \mathrm{U} / \mathrm{mL}$, without a mediator. Regardless of the initial amount of enzyme, its activity gradually declined throughout incubation time till there was no enzyme activity left in any of the soil microcosms after 14 days. Laccase transformed several PAH efficiently after $24 \mathrm{~h}$ of incubation, being anthracene and benzo[a]pyrene the most degradable. The total PAH removal by enzyme bioremediation in soil microcosms after 14 days ranged between $67.6 \%$ and $82.4 \%$ (Wu et al., 2008). In the current work, PAH degradation varied between $72 \%$ and $100 \%$ after 25 days of the assay, with $2 \mathrm{U} / \mathrm{mL}$ of laccase and $1 \mathrm{mM}$ of the mediator. The constant laccase/mediator feed in the PBR trials throughout the process allowed to work with the same activity levels during all the process, improving the degradation rates of $\mathrm{PAH}$ in soil.

\section{Conclusions}

Data from this study confirm previous observations suggesting the importance of mediators in the oxidation of PAH. The most commonly used mediator, ABTS, is too expensive for practical soil remediation, and the toxic effects from using it for long periods are unknown for now. Fortunately, natural mediators are capable of competing with the synthetic one, and in some cases good results can be obtained without a mediator, which suggests the possibility of other compounds present in the soil or in crude enzymes to enhance enzymatic oxidation. To make this degradation process more competitive, the laccase was produced from agricultural residue and crude laccase was used in all the assays, resulting in efficient degradation (high degradation rates), as well as faster and simpler process, when compared to degradation with microorganisms. The development of a laccase/mediator feeding system through packed bed reactor allowed to increase PAH degradation rate in soil, mainly of the benzo[a]pyrene, the most carcinogenic, mutagenic and persistent $\mathrm{PAH}$, probably due to the higher water availability to the system.

\section{CRediT authorship contribution statement}

Ziva Vipotnik: Conceptualization, Methodology, Investigation, Formal analysis, Writing - original draft. Michele Michelin: Conceptualization, Methodology, Validation, Writing - review \& editing, Supervision. Teresa Tavares: Conceptualization, Supervision, Writing review \& editing, Resources, Funding acquisition.

\section{Acknowledgements}

This study was supported by the Portuguese Foundation for Science and Technology (FCT)under the scope of the research project PTDC/ AAG-TEC/5269/2014, the strategic funding of UID/BIO/04469/2020 unit and COMPETE 2020 (POCI-01-0145-FEDER-006684) and BioTecNorte operation (NORTE-01-0145-FEDER-000004) funded by the European Regional Development Fundunder the scope of Norte2020 Programa Operacional Regional do Norte.

Ziva Vipotnik is a recipient of a fellowship supported by a doctoral advanced training (call NORTE-69-2015-15) funded by the European Social Fundunder the scope of Norte2020 - Programa Operacional Regional do Norte.

\section{References}

Aktaş, N., Tanyolaç, A., 2003. Reaction conditions for laccase catalyzed polymerization of catechol. Bioresour. Technol. 87, 209-214. https://doi.org/10.1016/S0960-8524 (02)00254-7.

Alexander, J., Benford, D., Cockburn, A., Cravedi, J., Dogliotti, E., Di Domenico, A., Fernández-cruz, M.L., Fink-gremmels, J., Fürst, P., Galli, C., Grandjean, P., Gzyl, J., Heinemeyer, G., Johansson, N., Mutti, A., Schlatter, J., Van Leeuwen, R., Van Peteghem, C., Verger, P., 2008. Polycyclic aromatic hydrocarbons in food - scientific opinion of the panel on contaminants in the food chain. EFSA J. 6, 1-114. https:// doi.org/10.2903/j.efsa.2008.724.

Allard, A., Remberger, M., Neilson, A.H., 2000. The negative impact of aging on the loss of PAH components in a creosote-contaminated soil. Int. Biodeterior. Biodegradation 46, 43-49. https://doi.org/10.1016/S0964-8305(00)00050-0.

Bamforth, S.M., Singleton, I., 2005. Bioremediation of polycyclic aromatic hydrocarbons: current knowledge and future directions. J. Chem. Technol. Biotechnol. 80, 723-736. https://doi.org/10.1002/jctb.1276.

Bhattacharya, S., Das, A., Prashanthi, K., Palaniswamy, M., Angayarkanni, J., 2014. Mycoremediation of Benzo[a]pyrene by Pleurotus ostreatus in the presence of heavy metals and mediators. 3 Biotech 4, 205-211. https://doi.org/10.1007/s13205-0130148-y.

Böhmer, U., Frömmel, S., Bley, T., Müller, M., Frankenfeld, K., Miethe, P., 2011. Solidstate fermentation of lignocellulotic materials for the production of enzymes by the white-rot fungus Trametes hirsuta in a modular bioreactor. Eng. Life Sci. 11, 395-401. https://doi.org/10.1002/elsc.201000162.

Bonomo, R., Cennamo, G., Purrello, R., Santoro, A., Zappalà, R., 2001. Comparison of three fungal laccases from Rigidoporus lignosus and Pleurotus ostreatus: correlation between conformation changes and catalytic activity. J. Inorg. Biochem. 83, 67-75. https://doi.org/10.1016/S0162-0134(00)00130-6. 
Bourbonnais, R., Paice, M.G., 1990. Oxidation of Non-phenolic Substrates. An Expanded Role for Lactase in Lignin Biodegradation. FEBS Lett. 267, pp. 99-102.

Brijwani, K., Vadlani, P.V., 2011. Cellulolytic enzymes production via solid-state fermentation: effect of pretreatment methods on physicochemical characteristics of substrate. Enzyme Res. 2011 https://doi.org/10.4061/2011/860134.

Brijwani, K., Rigdon, A., Vadlani, P.V., 2010. Fungal laccases: production, function, and applications in food processing. Enzyme Res. 2010 https://doi.org/10.4061/2010/ 149748.

Cañas, A.I., Alcalde, M., Plou, F., Martínez, M.J., Martínez, Á.T., Camarero, S., 2007. Transformation of polycyclic aromatic hydrocarbons by laccase is strongly enhanced by phenolic compounds present in soil. Environ. Sci. Technol. 41, 2964-2971. https://doi.org/10.1021/es062328j.

Chenthamarakshan, A., Parambayil, N., Miziriya, N., Soumya, P.S., Lakshmi, M.S.K., Ramgopal, A., Dileep, A., Nambisan, P., 2017. Optimization of laccase production from Marasmiellus palmivorus LA1 by Taguchi method of Design of experiments. BMC Biotechnol. 17, 1-10. https://doi.org/10.1186/s12896-017-0333-x.

Couto, S.R., Toca-Herrera, J.L., 2007. Laccase production at reactor scale by filamentous fungi. Biotechnol. Adv. 25, 558-569. https://doi.org/10.1016/J. BIOTECHADV.2007.07.002.

Dias, M., Caleja, C., Pereira, C., Calhelha, R.C., Kostic, M., Sokovic, M., Tavares, D., Baraldi, I.J., Barros, L., Ferreira, I.C.F.R., 2020. Chemical composition and bioactive properties of byproducts from two different kiwi varieties. Food Res. Int. 127, 108753 https://doi.org/10.1016/j.foodres.2019.108753.

Du, W., Sun, C., Liang, J., Han, Y., Yu, J., Liang, Z., 2015. Improvement of laccase production and its characterization by mutagenesis. J. Food Biochem. 39, 101-108. https://doi.org/10.1111/jfbc.12111.

Fernández-Fernández, M., Sanromán, M.Á., Moldes, D., 2013. Recent developments and applications of immobilized laccase. Biotechnol. Adv. 31, 1808-1825. https://doi. org/10.1016/J.BIOTECHADV.2012.02.013.

Ghosal, D., Ghosh, S., Dutta, T.K., Ahn, Y., 2016. Current state of knowledge in microbial degradation of polycyclic aromatic hydrocarbons (PAHs): a review. Front. Microbiol. 7, 1369. https://doi.org/10.3389/fmicb.2016.01837.

Góralczyk-Binkowska, A., Jasinska, A., Dlugonski, A., Plocinski, P., Dlugonski, J., 2020. Laccase activity of the ascomycete fungus Nectriella pironii and innovative strategies for its production on leaf litter of an urban park. PLoS One 15, 1-18. https://doi.org/ 10.1371/journal.pone.0231453.

Hailei, W., Ping, L., Yuhua, Y., Yufeng, L., 2015. Overproduction of laccase from a newly isolated Ganoderma lucidum using the municipal food waste as main carbon and nitrogen supplement. Bioprocess Biosyst. Eng. 38, 957-966. https://doi.org/ 10.1007/s00449-014-1341-z.

Han, M.-J., Choi, H.-T., Song, H.-G., 2004. Degradation of phenanthrene by Trametes versicolor and its laccase. J. Microbiol. 42, 94-98.

Haritash, A.K., Kaushik, C.P., 2009. Biodegradation aspects of Polycyclic Aromatic Hydrocarbons (PAHs): A review. J. Hazard. Mater. 169, 1-15. https://doi.org/ 10.1016/J.JHAZMAT.2009.03.137.

Hu, H.L., van den Brink, J., Gruben, B.S., Wösten, H.A.B., Gu, J.-D., de Vries, R.P., 2011. Improved enzyme production by co-cultivation of Aspergillus niger and Aspergillus oryzae and with other fungi. Int. Biodeterior. Biodegradation 65, 248-252. https:// doi.org/10.1016/J.IBIOD.2010.11.008.

Huesemann, M.H., Hausmann, T.S., Fortman, T.J., 2004. Does bioavailability limit biodegradation? A comparison of hydrocarbon biodegradation and desorption rates in aged soils. Biodegradation 15, 261-274. https://doi.org/10.1023/B: BIOD.0000042996.03551.f4.

Ike, P.T.L., Birolli, W.G., dos Santos, D.M., Porto, A.L.M., Souza, D.H.F., 2019. Biodegradation of anthracene and different PAHs by a yellow laccase from Leucoagaricus gongylophorus. Environ. Sci. Pollut. Res. 26, 8675-8684. https://doi. org/10.1007/s11356-019-04197-z.

Jin, X., Yu, X., Zhu, G., Zheng, Z., Feng, F., Zhang, Z., 2016. Conditions optimizing and application of laccase-mediator system (LMS) for the laccase-catalyzed pesticide degradation. Sci. Rep. 6, 35787. https://doi.org/10.1038/srep35787.

Johannes, C., Majcherczyk, A., 2000. Natural mediators in the oxidation of polycyclic aromatic hydrocarbons by laccase mediator systems. Appl. Environ. Microbiol. 66, 524-528. https://doi.org/10.1128/AEM.66.2.524-528.2000.

Kadri, T., Rouissi, T., Kaur Brar, S., Cledon, M., Sarma, S., Verma, M., 2017. Biodegradation of polycyclic aromatic hydrocarbons (PAHs) by fungal enzymes: a review. J. Environ. Sci. (China). 51, 52-74. https://doi.org/10.1016/j. jes.2016.08.023.

Keith, L.H., 2015. The source of U.S. EPA's sixteen PAH priority pollutants. Polycycl. Aromat. 35, 147-160. https://doi.org/10.1080/10406638.2014.892886.

Kirst Tychanowicz, G., De Souza, D.F., Souza, C.G.M., Kadowaki, M.K., Peralta, R.M., 2006. Copper improves the production of laccase by the white- rot fungus pleurotu pulmonarius in solid state fermentation. Braz. Arch. Biol. Technol. 49, 699-704.

Kunamneni, A., Plou, F.J., Ballesteros, A., Alcalde, M., 2008. Laccases and their applications: a patent review. Recent Pat. Biotechnol. 2, 10-24.

Lang, E., Gonser, A., Zadrazil, F., 2000. Influence of incubation temperature on activity of ligninolytic enzymes in sterile soil by Pleurotus sp. And Dichomitus squalens. J. Basic Microbiol. 40, 33-39. https://doi.org/10.1002/(SICI)1521-4028(200002) 40:1<33::AID-JOBM33>3.0.CO;2-Q.

Li, X., Lin, X., Yin, R., Wu, Y., Chu, H., Zeng, J., Yang, T., 2010. Optimization of laccasemediated benzo[a]pyrene oxidation and the bioremedial application in aged polycyclic aromatic hydrocarbons-contaminated soil. J. Health Sci. 56 (5), 534-540. Levin, R.D., Lias, S.G., 1982. Ionization Potential and Appearance Potential Measurements, 1971-1981. NSRDS-NBS 71, p. 634.

Li, X., La, G., Cheng, Q., Wang, F., Feng, F., Zhang, B., Zhang, Z., 2014a. Profile of natural redox mediators production of laccase-producing fungus Pleurotus ostreatus. Bull.
Environ. Contam. Toxicol. 93, 478-482. https://doi.org/10.1007/s00128-014-13404.

Li, Y., Shao, J., Wang, X., Deng, Y., Yang, H., Chen, H., 2014b. Characterization of modified biochars derived from bamboo pyrolysis and their utilization for target component (furfural) adsorption. Energy Fuels. https://doi.org/10.1021/ef500725c.

Li, C., Zhang, X., Gao, X., Qi, S., Wang, Y., 2019. The potential environmental impact of PAHs on soil and water resources in air deposited coal refuse sites in niangziguan karst catchment, Northern China. Int. J. Environ. Res. Public Health 16 (8), 1368. https://doi.org/10.3390/ijerph16081368.

Liu, Y., Hua, X., 2014. Degradation of acenaphthylene and anthracene by chemically modified laccase from Trametes versicolor. RSC Adv. 4, 31120-31122.

Luo, L., Lin, S., Huang, H., Zhang, S., 2012. Relationships between aging of PAHs and soil properties. Environ. Pollut. 170, 177-182. https://doi.org/10.1016/j envpol.2012.07.003.

Martin, A., 2000. Aging, Bioavailability, and Overestimation of Risk From Environmental Pollutants. Environ. Sci. Technol. 34 (20), 4259--4265.

Meehnian, H., Jana, A.K., Jana, M.M., 2017. Pretreatment of cotton stalks by synergistic interaction of Daedalea flavida and Phlebia radiata in co-culture for improvement in delignification and saccharification. Int. Biodeterior. Biodegrad. 117, 68-77. https:// doi.org/10.1016/j.ibiod.2016.11.022.

Mosleh, S., Rahimi, M.R., Ghaedi, M., Dashtian, K., Hajati, S., 2016. Photocatalytic degradation of binary mixture of toxic dyes by HKUST-1 MOF and HKUST-1-SBA-15 in a rotating packed bed reactor under blue LED illumination: central composite design optimization. RSC Adv. 6, 17204-17214. https://doi.org/10.1039/ C5RA24564H.

Mosleh, S., Rahimi, M.R., Ghaedi, M., Dashtian, K., Hajati, S., Wang, S., 2017. Ag3PO4/ AgBr/Ag-HKUST-1-MOF composites as novel blue LED light active photocatalyst for enhanced degradation of ternary mixture of dyes in a rotating packed bed reactor. Chem. Eng. Process. - Process Intensif. 114, 24-38. https://doi.org/10.1016/j. cep.2017.01.009.

Mosleh, S., Rahimi, M.R., Ghaedi, M., Dashtian, K., Hajati, S., 2018. Sonochemicalassisted synthesis of $\mathrm{CuO} / \mathrm{Cu} 2 \mathrm{O} / \mathrm{Cu}$ nanoparticles as efficient photocatalyst for simultaneous degradation of pollutant dyes in rotating packed bed reactor: LED illumination and central composite design optimization. Ultrason. Sonochem. 40, 601-610. https://doi.org/10.1016/j.ultsonch.2017.08.007.

Munusamy, U., Sabaratnam, V., Muniandy, S., Abdullah, N., Pandey, A., Jones, E.B.G., 2008. Biodegradation of polycyclic aromatic hydrocarbons by laccase of Pycnoporus sanguineus and toxicity evaluation of treated PAH. Biotechnology 7, 669-677. https://doi.org/10.3923/biotech.2008.669.677.

Nyanhongo, G.S., Gomes, J., Gübitz, G., Zvauya, R., Read, J.S., Steiner, W., 2002. Production of laccase by a newly isolated strain of Trametes modesta. Bioresour. Technol. 84, 259-263. https://doi.org/10.1016/S0960-8524(02)00044-5.

Ogbonna, D.N., Ideriah, T.J.K., Nwachukwu, M.I., 2012. Biodegradation of polycyclic aromatic hydrocarbons by associated microbes from abattoir wastes in the Niger Delta. Nigeria. J. Microbiol. Res. 2, 157-169. https://doi.org/10.5923/j. microbiology.20120206.02.

Patel, H., Gupte, A., 2016. Optimization of different culture conditions for enhanced laccase production and its purification from Tricholoma giganteum AGHP. Bioresour. Bioprocess. 3 https://doi.org/10.1186/s40643-016-0088-6.

Pozdnyakova, N.N., Rodakiewicz-Nowak, J., Turkovskaya, O.V., Haber, J., 2006. Oxidative degradation of polyaromatic hydrocarbons and their derivatives catalyzed directly by the yellow laccase from Pleurotus ostreatus D1. J. Mol. Catal., B Enzym. 41, 8-15. https://doi.org/10.1016/j.molcatb.2006.04.002.

Punnapayak, H., Prasongsuk, S., Messner, K., Danmek, K., Lotrakul, P., 2009. Polycyclic aromatic hydrocarbons (PAHs) degradation by laccase from a tropical white rot fungus Ganoderma lucidum. African J. Biotechnol. 8, 5897-5900.

Rodríguez Couto, S., Sanromán, M.A., 2005. Application of solid-state fermentation to ligninolytic enzyme production. Biochem. Eng. J. 22, 211-219. https://doi.org/ 10.1016/J.BEJ.2004.09.013.

Rodríguez Couto, S., Moldes, D., Liébanas, A., Sanromán, A., 2003. Investigation of several bioreactor configurations for laccase production by Trametes versicolor operating in solid-state conditions. Biochem. Eng. J. 15, 21-26. https://doi.org/ 10.1016/S1369-703X(02)00180-8.

Rodríguez-Couto, S., 2011. Production of laccase and decolouration of the textile dye Remazol Brilliant Blue R in temporary immersion bioreactors. J. Hazard. Mater. 194, 297-302. https://doi.org/10.1016/j.jhazmat.2011.07.098.

Rosales, E., Couto, S.R., Sanromán, M.Á., 2005. Reutilisation of food processing wastes for production of relevant metabolites: application to laccase production by Trametes hirsuta. J. Food Eng. 66, 419-423. https://doi.org/10.1016/j. jfoodeng.2004.04.010.

Rosales, E., Rodríguez Couto, S., Sanromán, M.A., 2007. Increased laccase production by Trametes hirsuta grown on ground orange peelings. Enzyme Microb. Technol. 40, 1286-1290. https://doi.org/10.1016/J.ENZMICTEC.2006.09.015.

Singh Nee Nigam, P., Pandey, A., 2009. Biotechnology for Agro-industrial Residues Utilisation: Utilisation of Agro-residues. Springer, Netherlands.

Soquetta, M.B., Stefanello, F.S., Huerta, K.D.M., Monteiro, S.S., Da Rosa, C.S., Terra, N. N., 2016. Characterization of physiochemical and microbiological properties, and bioactive compounds, of flour made from the skin and bagasse of kiwi fruit (Actinidia deliciosa). Food Chem. 199, 471-478. https://doi.org/10.1016/j foodchem.2015.12.022.

Stredansky, M., Conti, E., 1999. Xanthan production by solid state fermentation. Process Biochem. 34 (6-7), 581-587. https://doi.org/10.1016/S0032-9592(98)00131-9.

Strong, P.J., 2011. Improved laccase production by trametes pubescens MB89 in distillery wastewaters. Enzyme Res. 2011 https://doi.org/10.4061/2011/379176.

Styrishave, B., Björklund, E., Johnsen, A., Halling-Sørensen, B., 2012. The spatial heterogeneity of polycyclic aromatic hydrocarbons in soil depends on their physico- 
chemical properties. Water Air Soil Pollut. 223, 969-977. https://doi.org/10.1007/ s11270-011-0916-4.

Thurston, C.F., 1984. The Structure and Function of Fungal Laccases. Microbiology, pp. 19-26.

Upadhyay, P., Shrivastava, R., Agrawal, P.K., 2016. Bioprospecting and biotechnologica applications of fungal laccase. 3 Biotech 6, 1-12. https://doi.org/10.1007/s13205applications

Vasconcelos, A.F.D., Barbosa, A.M., Dekker, R.F.H., Scarminio, I.S., Rezende, M.I., 2000. Optimization of laccase production by Botryosphaeria sp. In the presence of veratryl alcohol by the response-surface method. Process Biochem. 35, 1131-1138. https:// doi.org/10.1016/S0032-9592(00)00149-7.

Viswanath, B., Rajesh, B., Janardhan, A., Kumar, A.P., Narasimha, G., 2014. Fungal laccases and their applications in bioremediation. Enzyme Res. 2014, 1-21. https:// doi.org/10.1155/2014/163242.

Wang, X., Sun, S.Y., Ni, Z.J., Li, Z.X., Bao, J., 2018. Degradation of polycyclic aromatic hydrocarbons in contaminated soil by immobilized laccase. J. Serbian Chem. Soc. 83, 549-559. https://doi.org/10.2298/JSC171004022W.
Wu, Y., Teng, Y., Li, Z., Liao, X., Luo, Y., 2008. Potential role of polycyclic aromatic hydrocarbons (PAHs) oxidation by fungal laccase in the remediation of an aged contaminated soil. Soil Biol. Biochem. 40, 789-796. https://doi.org/10.1016/j. soilbio.2007.10.013.

Xu, P., Du, H., Peng, X., Tang, Y., Zhou, Y., Chen, X., Fei, J., Meng, Y., Yuan, L., 2020. Degradation of several polycyclic aromatic hydrocarbons by laccase in reverse micelle system. Sci. Total Environ. 708, 134970. https://doi.org/10.1016/j. scitotenv.2019.134970.

Zhang, J., Liu, X., Xu, Z., Chen, H., Yang, Y., 2008. Degradation of chlorophenols catalyzed by laccase. Int. Biodeterior. Biodegradation 61, 351-356. https://doi.org/ 10.1016/J.IBIOD. 2007.06.015.

Zhang, M., Ahmad, M., Lee, S.S., Xu, L.H., Ok, Y.S., 2014. Sorption of polycyclic aromatic hydrocarbons (PAHs) to lignin: effects of hydrophobicity and temperature. Bull. Environ. Contam. Toxicol. 93 (1), 84-88. https://doi.org/10.1007/s00128-0141290-x. 